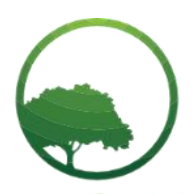

Research in Business \& Social Science

\title{
The impact of the oil palm plantation area on the community economy in East Kutai Regency, East Kalimantan \\ Crossref
}

Zulkarnain@(a), Muhammad Erwan Suriaatmaja $(b)$

(a,b)Faculty of Agriculture, Mulawarman University, Samarinda, Indonesia

\begin{tabular}{l} 
A R T I C L E I N F O \\
\hline Article history: \\
Received 03 June 20 \\
Received in revised form 18 June 20 \\
Accepted 22 June 20 \\
\hline Keywords: \\
Plantation area, cost of benefits, \\
welfare. \\
\hline JEL Classification: \\
Q02, Q56
\end{tabular}

\begin{abstract}
A B S T R A C T
This article is about how the impact of change and the extent of existing activities contribute to the surrounding community. The development of large private plantations in East Kutai Regency has also been inseparable from problems, especially in the management of plasma plantations carried out by large plantation companies. Issues that arise include the difference in productivity between nucleus and plasma plantations, the low acceptance of plasma farmers so that it is considered not to improve the welfare of the community. The purpose of this study was to determine the impact of large private plantations on community welfare, evaluating the implementation of plantation development activities in East Kutai Regency. The sampling method is done by purposed sampling using data analysis methods, the analysis of the cost of the benefits of the area, the analysis of the level of welfare and analysis of regional influence. With the results of the study as follows: the cost of benefits is positive; the multiplier value is 2,614 and the value of NTM is 0.37 .
\end{abstract}

(C) 2020 by the authors. Licensee SSBFNET, Istanbul, Turkey. This article is an open access article distributed under the terms and conditions of the Creative Commons Attribution (CC BY) license (http://creativecommons.org/licenses/by/4.0/).

\section{Introduction}

In order to accelerate the achievement of people's welfare, the Government has a strong commitment to achieve development targets. Therefore, the welfare of the people in this study was measured through the Human Development Index (HDI), which in Indonesia is known as the Human Development Index (HDI). It means the government must have a strong commitment to increase the HDI rate. One of the government's efforts to increase growth and welfare of the community through the level of economic growth that is driven by a conducive business environment is expected to increase investors in investing their capital which is further expected to increase the prosperity and welfare of the people in their environment.

The development of oil palm commodities is also carried out in East Kutai Regency which is one of the centers of oil palm plantations in East Kalimantan Province. This is reflected in the very significant growth of oil palm planted area in the last ten years. In 2000 , the area of oil palm plantations in East Kutai Regency only reached 1,235 ha, then in 2015 it had increased to 400 thousand ha with the distribution in almost all districts in East Kutai Regency. The area of oil palm plantations is expected to continue to increase with the target of developing oil palm plantations of 500 thousand hectares in East Kutai Regency. The availability of extensive land resources with a good condition of land agroecosystems and policy support are factors that drive the growth of oil palm commodities in this region.

The development of palm oil commodities in East Kutai Regency is in line with the regional government program that will make East Kutai Regency an agribusiness and ago industrial center so that the growth of these commodities continues to be driven. The government not only encourages the development of oil palm up to the stage of production on land, but also to the development of the downstream palm oil industry.

* Corresponding author. ORCID ID: 0000-0003-4194-449X

(C) 2020 by the authors. Hosting by SSBFNET. Peer review under responsibility of Center for Strategic Studies in Business and Finance. https://doi.org/10.20525/ijrbs.v9i4.754 
For people in rural areas in East Kutai Regency, until now the oil palm plantation business is an alternative to improve the family economy, therefore the public interest in the development of oil palm plantations is still high. According to Syahza (2011) oil palm farming shows an increase in the welfare of farmers in rural areas.

The presence of large private plantations in rural areas also raises negative issues, especially in social issues and rural and environmental development. The social issues of oil palm plantations include oil palm plantations only owned by large corporations so that they do not have a direct impact on the welfare of the community. In addition, the vast use of land for plantations has triggered agrarian conflicts. While from environmental issues, oil palm causes floods and droughts that directly impact local communities.

Considering the growth of private large plantations in East Kutai District which is very significant and the high economic dependence of the community on these commodities, it is necessary to study the effect of large private plantation activities on community welfare. The location of this study was conducted in the Districts of Muara Wahau and Kongbeng which are the centers of oil palm plantations in East Kutai Regency. The results of this study are expected to provide input for local governments in taking the policy of developing oil palm plantations in East Kutai Regency.

The presence of large private plantations in East Kutai Regency has stimulated regional growth thus giving rise to new growth centers. There is a policy that requires companies to develop partnerships with communities by building plasma plantations directly adding to the income of the people who are members of the partnership. In addition, the operation of large plantations which also involve the activities of the palm oil processing industry encourages the development of independent smallholder plantations. The existence of large private plantations also provides employment for local communities and raises a multiplier effect in the form of the development of the service sector and trade and more open accessibility to areas that have been including remote areas.

The development of large private plantations in East Kutai Regency has also been inseparable from problems, especially in the management of plasma plantations carried out by large plantation companies. Issues that arise include the difference in productivity between nucleus and plasma plantations, the low acceptance of plasma farmers so that it is considered not to improve the welfare of the community.

Based on the background and formulation of the problems stated above, this research aims to (i) know the impact of large private plantations on community welfare, and (ii) evaluating the implementation of plantation development activities program in East Kutai Regency.

\section{Literature Review}

The development of plantations in rural areas has opened job opportunities for people who are able to accept these opportunities. With the establishment of plantation companies, the local people's livelihoods are no longer limited to the primary sector in meeting the needs of their families but have expanded their business space to the tertiary sector. Various sources of income that contribute are traders (trading in daily goods, rubber trading, transportation tickets and ice sellers), employees (teachers, village government), home industries (tofu, bread and tile printing industries), unskilled laborers, fishermen, forest hunters and carpenters.

In general, it can be revealed that the existence of plantation areas has led to the emergence of new sources of income that vary. Before the opening of plantation estates in rural areas, the sample revealed a relatively homogeneous source of community income, that is, relying on primary sectors, utilizing available natural resources as they are without the use of meaningful technology. Field data reveals that in general the people live from the agricultural sector as food crop farmers (mainly palawija) and plantations (rubber). In the communities around the river, the daily livelihood is generally as fishermen and wood collectors in the forest. In addition, the technology used is very simple and monotonous in nature without renewal (of what it can do). Business orientation is also limited to meeting the needs of the family for the next one or two days without a clear business development plan.

Plantation development activities have led to high population mobility. As a result, in the areas around plantation development, centers of economic growth have emerged in rural areas. This condition has led to increased purchasing power of rural communities, especially towards routine household needs and the need for palm oil plantation production facilities.

The prospect of oil palm plantations is indeed very promising so that oil palm farming that is cultivated in the form of plantations has penetrated in various villages in the East Kutai Regency. Plantations in East Kutai Regency are scattered in various villages within the subdistrict, one of which is the Districts of Muara Wahau and Kongbeng, which has a very rapid development of land, production and productivity of oil palm every year.

The existence of oil palm plantations can cause social change and social mobility in the area. This is caused by the large-scale activities that can make these changes occur which are supported by contact with other cultures that originate from the amount of migration due to the opportunities created by these activities. The education system developed because of changes in income structure and other cultural interactions. It can also encourage change and social mobility. Therefore, it can encourage social class groupings based on economic status, social status and political status.

The company's project activities will have an impact with the opening of business opportunities. Even though the type of business that can be utilized by residents is still classified in intensity and small scale, but it has a positive impact on the economy of the community around the palm oil company project. The increasingly complex activities of oil palm plantations will open employment 
opportunities directly for the community around the company to become employees in the company. This is supported by the implementation of regional autonomy which prioritizes local communities. Procurement of work on projects for plantation activities will have an impact on community income. The increase in income can be felt directly or indirectly by the community around the plantation company.

The establishment of a palm oil company as an asset of the regional economy will have an indirect impact on the economy and regional development through an increase in the region's original income derived from levies and local taxes.

\section{Framework}

Most of the oil palm plantations in East Kutai Regency are managed by large private plantation companies. To date, there are 87 oil palm plantation companies in East Kutai Regency with a total planting area of 287 thousand ha with 19 palm oil processing factories (PKS). The existence of large private plantations can absorb large numbers of workers and increase the income of oil palm farmers both plasma farmers and independent farmers so that it impacts on improving the welfare of the community. However, the existence of oil palm plantations can also cause negative impacts on the physical and social environment, such as pollution the environment and the rise of social conflict.

The initial stage of the research is to inventory the characteristics of the area/region/population to determine the condition of the area of the location of the large private plantations that have been declared by the government of East Kutai Regency. Furthermore, welfare indicators are determined. Welfare indicators can be in the form of a single indicator such as education, health and the economy, as well as composite indicators such as the human development index, the human poverty index.

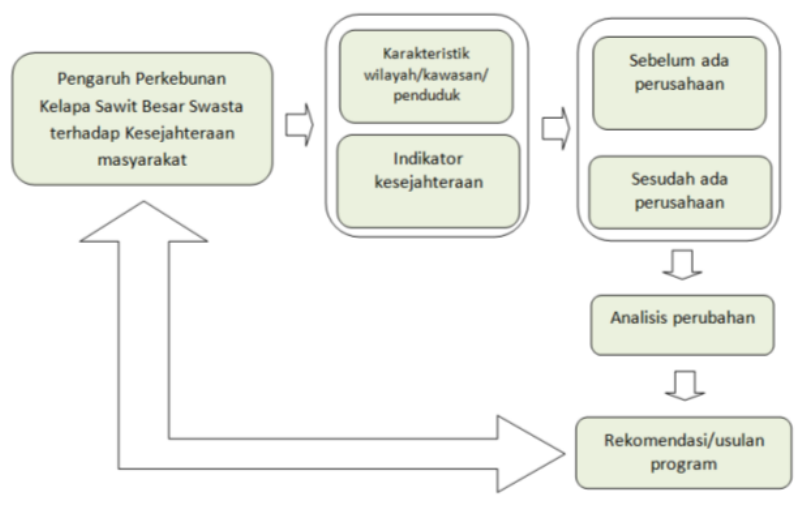

Figure 1: Original framework for thinking flow

Analysis of the potential and problems of problems before and after the existence of plantations. To find out changes in community welfare due to the existence of private large plantations can be done by comparing the welfare indicators before and after the existence of large private plantations. The analytical method used is a quantitative approach with statistical analysis. The final stage of this study is to formulate recommendations as input in taking the policy of developing large private plantations to improve community welfare in East Kutai Regency.

\section{Research and Methodology}

\section{Research Location and Time}

The location of the activities of the Effect of Private Large Plantation Activities on Community Welfare administratively covers 2 (two) districts, namely Kongbeng dam Muara Wahau. The Effect of Private Large Plantation Activities on Community Welfare was carried out for six months, from April to September 2016, which included preparation, data collection and field surveys, data analysis and report preparation. 


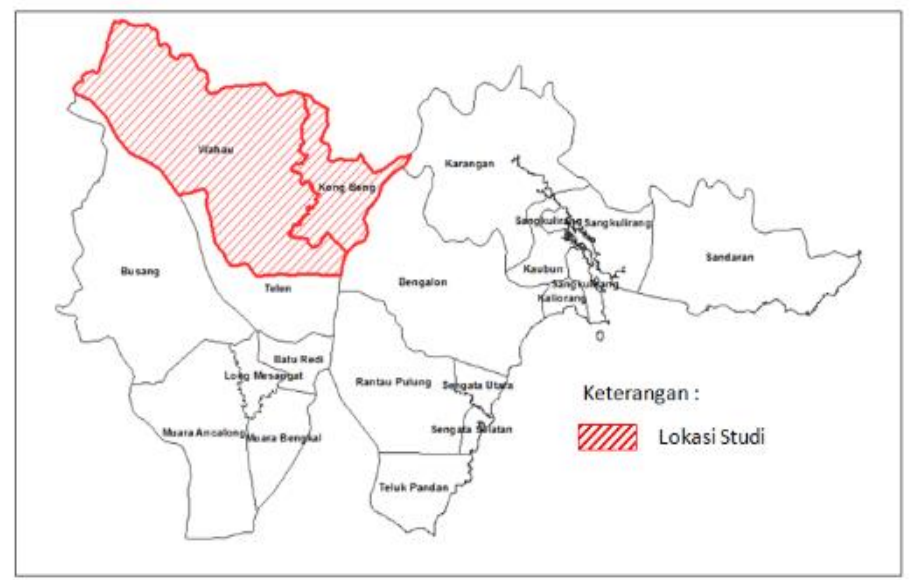

Figure 2: Study location

\section{Sampling Method}

Types and sources of data used in this study include primary data and secondary data. Primary data were obtained from direct interviews using questionnaires or questionnaires. The determination of the sub-districts was carried out in a deliberate way, namely the Districts of Muara Wahau and the District of Kongbeng, while the determination of respondents was carried out using a puposed sampling. Respondents include:

- Oil palm growers

- Plasma managers / cooperatives

- Plantation workers

- Government officials: sub-district / village head, Dinas Perkebunan

Secondary data were obtained from government agencies that deal with plantation commodities in general and oil palm (Plantation Office, Statistics Office, District Office, Village Office, etc.). Secondary data collected includes:

- Company name and area of IUP of oil palm plantations

- Plasma area and community garden area

- Number of oil palm farmer groups and number of oil palm farmers

- The number of workers in large private plantations

- Oil palm production in large private plantations and smallholder plantations

- Monograph data

\section{Model and Method of Analysis}

The data obtained were analyzed using data analysis methods, both qualitatively and quantitatively. The analysis includes an analysis of the influence of the regional economy, analysis of benefit costs, analysis of community welfare and analysis of contributions to regional income.

\section{Cost Benefit Analysis}

In this analysis the decision-making process is based on an analysis of the magnitude of the project "losses" that are transferred into the cost component and the project "profits" presented in the benefit component (netbenefit) are positive or in other words:

$\mathrm{Ba}-\mathrm{Ca}>0$

Where:

$\mathrm{Ba}=$ Benefits from the region (including environmental benefits)

$\mathrm{Ca}=$ Regional costs (including environmental costs)

\section{Analysis of Community Welfare Level}

To find out the level of community welfare, especially around the development of oil palm plantations, tests are carried out using the following formula:

$$
N T M=\frac{\hat{\mathrm{a}} p_{x i} q_{x i}}{\hat{\mathrm{a}} p_{y i} q_{y i}+\hat{\mathrm{a}} p_{y j} q_{y j}}
$$

Where: 
NT = Exchange rate

pxi $\quad=$ Commodity Prices

qxi = Commodity quantity

pyi $\quad=$ Price of production inputs

qyi $\quad=$ Production input quantity

pyj $\quad=$ Prices of household consumption goods

qyj = Quantity of household consumption goods

Conclusions drawn based on the exchange rates of people who are in the area of plantation activities are as follows:

$\mathrm{NTM}>1$ means prosperous, $\mathrm{NTM}=1$ means quite prosperous and $\mathrm{NTM}<1$ means less prosperous.

\section{Analysis of Regional Economic Effects}

To analyze the economic influence of the oil palm plantation area, the multiplier effect creation approach is used in the oil palm plantation activities by using:

$$
\mathrm{KS}=\frac{1}{1-(M P C \tilde{A}-P S Y)}
$$

Where:

$\mathrm{KS} \quad=$ Regional economic influence

MPC = Proportion of income spent in the activity area

PSY $=$ Part of farmers' expenditure

\section{Results and Discussion}

\section{The Effect of Large Private Plantations on the Regional Economy}

Large private plantation activities have led to the growth of economic growth centers in the area, thereby increasing people's purchasing power, especially towards routine household needs and the need for palm oil plantation production facilities. In terms of household needs the average expenditure is presented in table 1.1

Table 1: Average types of routine community expenditure around private oil palm plantations

\begin{tabular}{|r|l|r|r|r|r|}
\hline \multirow{2}{*}{ No } & \multirow{2}{*}{$\begin{array}{c}\text { Jenis } \\
\text { Pengeluaran }\end{array}$} & \multicolumn{2}{|c|}{ Plasma/TK Perusahaan } & \multicolumn{2}{|c|}{$\begin{array}{c}\text { Swadaya/Masyarakat } \\
\text { sekitar }\end{array}$} \\
\cline { 3 - 6 } & & Nilai (Rp) & \multicolumn{1}{c|}{$\%$} & \multicolumn{1}{c|}{ Nilai (Rp) } & \multicolumn{1}{c|}{$\%$} \\
\hline 1 & Dapur & 986.746 & 51,02 & 1.365 .786 & 47,61 \\
\hline 2 & Listrik & 153.897 & 7,96 & 168.986 & 5,89 \\
\hline 3 & Telekomunikasi & 67.950 & 3,51 & 87.654 & 3,06 \\
\hline 4 & Transportasi & 215.800 & 11,16 & 356.754 & 12,44 \\
\hline 5 & Kesehatan & 115.980 & 6,00 & 210.435 & 7,34 \\
\hline 6 & Rekreasi & 63.606 & 3,29 & 85.754 & 2,99 \\
\hline 7 & Pendidikan & 235.912 & 12,20 & 320.716 & 11,18 \\
\hline 8 & Investasi & 56.746 & 2,93 & 197.876 & 6,90 \\
\hline 9 & Sosial & 37.563 & 1,94 & 74.946 & 2,61 \\
\hline & Jumlah & $\mathbf{1 . 9 3 4 . 2 0 0}$ & $\mathbf{1 0 0}$ & $\mathbf{2 . 8 6 8 . 9 0 7}$ & $\mathbf{1 0 0}$ \\
\hline
\end{tabular}

Respondents in the community involved in the activities of large private companies consist of plasma farmers, and the company's workforce includes staff employees, non-staff and casual daily employees both from surrounding areas and migrants. The surrounding community and self-help actors who are directly or indirectly involved, are farmers who cultivate palm oil in the company's longterm area until market participants are formed by trading activities, including transportation services to the provision of input equipment. Indirectly are people who live in the area of large private plantation activities, for example, village officials, other service providers who benefit from these activities.

The biggest routine expenditure for plasma farmers and the workers of private plantation companies is kitchen expenses for daily necessities including the nine basic necessities by 51 percent, as well as for independent smallholders or the surrounding communities for the smallest expenditure is in the type of social expenditure. For day-to-day needs of the company's workforce more imported from outside the region as well as the needs of the community around a certain season still bring in from outside the area so that capital turnover is often utilized by areas outside the activities of large private plantations.

By using the multiplier formula, MPC value $=0.90$ and PSY value $=0.68$. So we get a multiplier of 2,614 . This value can give the meaning that every expenditure by farmers and the community around private plantation activities is Rp. 100, - synergistically makes the velocity of money in these locations Rp. 261, - through business forms, both the real sector and services. 


\section{Cost of Benefit from Large Private Estate Areas}

All costs incurred by oil palm plantation companies are the sum of all expenses within a certain year, to carry out certain activities, in accordance with the schedule of implementation of the activity. Costs that must be incurred by the company in implementing project activities include the costs of: 1) Obtaining Business Permit (HGU) for oil palm plantations, 2) investing in oil palm plants, 3) maintaining plants, 4) harvesting FFB, 5 ) fertilization, 6) transporting FFB to processing plants, 7) investment in plant construction, 8) costs of processing FFB into CPO and KPO, 9) transportation costs of CPO and KPO from PKS locations to export ports, 10) overhead costs, and 11) costs depreciation.

The total annual benefit received from carrying out oil palm plantation activities is the sum of all revenues within a certain one year, during the life period of the activity. Receipts in monetary value, obtained from the sale of CPO and KPO which are sold in the domestic market and those exported. Oil palm plants only start to produce FFB in the 4th year (3-year gestation period), so that project revenue from the sale of CPO and KPOs only starts to be produced in the 4th year, then continues until the 25 th year. The company's total revenue, starting from the 5th to the 25th years, ranges in value of Rp. 7,511,000, - Rp. 35,491,000 / ha / year. With a total production cost over the life span of activities ranging from: Rp. 4,876,000, - Rp. 23,674,000, - / ha / year.

In addition to the various costs and benefits as stated in the financial analysis section, in fact there are still other costs incurred (incurred) as a result of the conversion of natural forests to the development of oil palm plantations, namely environmental costs (environmental costs) and social costs ( social costs). The amount of environmental costs can be divided into high value and low value. High value is obtained based on the benefit transfer method, which is the result of research on tropical rainforest ecosystems in several countries (Ruitenbeek, 1999; Constanza, 1997). Low value and percentage "trust" factor are assumptions made based on conditions in Indonesia to obtain reasonable minimum values of environmental costs and social costs. Furthermore, these reasonable minimum values are used in the calculation of the economic valuation analysis of oil palm plantation investments. By using the analysis of benefit costs the benefits of the project (Ba) amounting to Rp 1,495,857,584,000.00 and the project cost (Ca) of Rp. $1,291,642,400,000.00$ of the total land area of $6,4582.12$ ha so that the cost of benefits is still positive.

\section{Community Welfare Level}

The concept of community exchange value is calculated from the ratio of the price received by the community to the price paid by the community in an existing activity so that this concept can simply describe the purchasing power of the people involved in a production activity both directly and indirectly. So that the concept of exchange rate is closer to the welfare conditions based on purchasing power, then through the concept of value, namely by entering the quantity element in the calculation so that it can address the ratio of income to expenditure value.

The exchange rates of people in private plantation areas are presented in Table 1.2 and Table 1.3. Community exchange rates for independent smallholders and communities around plantations in 2015 in Muara Wahau District were 0.11 while in Kongbeng District 0.07 . The exchange rates of the people in the study locations between 2011-2015 experienced a growth of 40.62\% for Muara Wahau District and $47.58 \%$ for Kongbeng District.

The exchange rate of the plasma plantation owners and oil palm company workers in 2015 in Muara Wahau Sub-district was 0.57 while in Kongbeng District was 0.17. The growth rate of the community's exchange rates between 2011-2015 was 21\% for Muara Wahau District and $1.21 \%$ for Kongbeng District.

Table 2: Exchange rates of community self-supporting plantations and communities surrounding private oil palm plantation activities

\begin{tabular}{|r|l|r|r|r|r|r|r|}
\hline \multirow{2}{*}{ No } & \multirow{2}{*}{ Kecamatan } & \multicolumn{5}{|c|}{ NTM } & \multicolumn{1}{c|}{ Rasio } \\
\cline { 3 - 7 } & & $\mathbf{2 0 1 1}$ & $\mathbf{2 0 1 2}$ & $\mathbf{2 0 1 3}$ & $\mathbf{2 0 1 4}$ & $\mathbf{2 0 1 5}$ & Pertumbuhan \\
\hline 1 & Muara Wahau & 0.02 & 0.03 & 0.04 & 0.07 & 0.11 & $40.62 \%$ \\
\hline 2 & Kongbeng & 0.01 & 0.02 & 0.03 & 0.04 & 0.07 & $47,58 \%$ \\
\hline
\end{tabular}

Table 3. Exchange rates of community plasma plantations and company workers around

private oil palm plantation activities

\begin{tabular}{|r|l|r|r|r|r|r|r|}
\hline \multirow{2}{*}{ No } & \multirow{2}{*}{ Kecamatan } & \multicolumn{5}{|c|}{ NTM } & \multirow{2}{*}{$\begin{array}{c}\text { Rasio } \\
\text { Pertumbuhan }\end{array}$} \\
\cline { 3 - 8 } & & $\mathbf{2 0 1 1}$ & $\mathbf{2 0 1 2}$ & $\mathbf{2 0 1 3}$ & $\mathbf{2 0 1 4}$ & $\mathbf{2 0 1 5}$ & $21 \%$ \\
\hline 1 & Muara Wahau & 0.22 & 0.25 & 0.32 & 0.41 & 0.57 & $1,21 \%$ \\
\hline 2 & Kongbeng & 0.16 & 0.16 & 0.15 & 0.18 & 0.17 & \\
\hline
\end{tabular}




\section{Conclusions}

By using the multiplier formula, MPC value $=0.90$ and PSY value $=0.68$. So we get a multiplier of 2,614 . This value can give the meaning that every expenditure by farmers and the community around private plantation activities is Rp. 100, - synergistically makes the velocity of money in these locations Rp. 261, - through business forms, both the real sector and services. The percentage of community income spent on the area of private oil palm plantations is around $90 \%$. The needs of private plantation activities that can be met in the local area by $68 \%$, this is because there are still a lot of equipment needs for production facilities that can not be produced in the area around private plantations.

By using the cost benefit analysis the benefits obtained from the project (Ba) are Rp. 1,495,857,584,000.00 and the project cost (Ca) is Rp. 1,291,642,400,000.00 of the total land area of 64582.12 ha so that the cost of benefits is still positive.

In table 1.3 the growth ratio of plasma plantations and company labor around private plantation activities in Kongbeng District has a very low NTM growth ratio of $1.21 \%$ while Muara Wahau District has a growth rate of $21 \%$. As seen in tables 1.2 and 1.3 the level of welfare is more enjoyed by the plasma plantation community and private plantation company workers.

To overcome the problems that exist in this phenomenon because existing investments are held solely by the private sector so that only prioritizes profit alone. To obtain the principle of benefits from any large-scale plantation or investment activities, the role of the government in this case must have a greater share so that the principle of benefits from each investment activity involving the private sector contributes to the region itself and the community directly.

In addition to the various costs and benefits as stated in the financial analysis section, there are actually other costs incurred (incurred) as a result of natural forest conversion activities for the development of oil palm plantations, namely environmental costs and environmental costs social (social costs). The amount of environmental costs can be divided into high value and low value. High value is obtained based on the benefit transfer method, which is the result of research on tropical rainforest ecosystems in several countries (Ruitenbeek, 1999; Constanza, 1997). Low value and percentage "trust" factor are assumptions made based on conditions in Indonesia to obtain reasonable minimum values of environmental costs and social costs. Furthermore, these reasonable minimum values are used in the calculation of the economic valuation analysis of oil palm plantation investments.

Many factors affect income and consumption patterns of the community around large private plantation activities, in terms of income can be seen in income from farming, outside farming or business outside agricultural activities such as employees, traders, services and others. The amount of income from agricultural business is influenced by the size of production assets (ownership of business land), the type of commodity being cultivated, productivity, market access and production prices. While other businesses outside agricultural activities are seen from the ability to be able to access services, the business climate, skills in taking opportunities and the support of local governments.

\section{References}

Abdullah et al (2008) An Empirical Study of Knowledge Management System Implementation in Public Higher Learning Institution, IJCSNS International Journal of Computer Science and Network Security, 8(1), 281-290

Afifuddin, S., Kusuma, SI. 2007. Analisis Struktur Pasar CPO: Pengaruhnya terhadap pengembangan ekonomi wilayah Sumater Utara. Jurnal Perencanaan dan Pengembangan Wilayah. 2(3), 124 -136.

Ambardi, U.M. 2002. Pendapatan Asli Daerah dan Dana Perimbangan Sebagai Sumber Pendapatan Daerah. Dalam Pengembangan Wilayah dan Otonomi Daerah. BPPT. Jakarta.

Arsyad, AR. Heri Junaedi, dan Yulfita Farni. 2012. Pemupukan Kelapa Sawit Berdasarkan Potensi Produksi Untuk Meningkatkan Hasil Tandan Buah Segar (TBS) Pada Lahan Marginal Kumpeh. Jurnal Penelitian Universitas Jambi. 14(1), 29.

Cullis, J.G. and P.R. Jones (1992) Public Final and Public Choice: Analytical Pespectives, Mc-Graw-Hill.

Constanza R et al. 1997. The value of the world's ecosystem services and natural capital. J.Nature. 387:253-260.

David, Fred R., 2006. Manajemen Strategis. Edisi Sepuluh, Penerbit Salemba Empat, Jakarta

de Neufville, R. 1990. Applied System Analysis : Engineering Planning and Technology Management, McGraw-Hill, Inc.

Eatwell, J., M. Milgate, and P. Newman. 1987. The New Palgrave a Dictionary of Economics, 3, The Macmillan Press Limited, London.

Field, B.C. (1994) Environmental Economics: an Introduction, McGraw-Hill, Inc.

Husin, L. 2013. Penggunaan Model Rumah Tangga Petani untuk Mengkaji Perilaku Ekonomi Rumah Tangga Petani Kelapa Sawit di Sumatera Selatan. http://eprints.unsri.ac.id/1600/. Accessed December 19, 2013.

Kadir, H. Dan Syapsan. 2012. Peranan Perkebunan Kelapa Sawit dalam Menyerap Tenaga Kerja di Kabupaten Rokan Hulu. Jurnal Sosial Ekonomi Pembangunan. III(7), 24 - 32.

Mangkoesoebroto, G. 1998. Ekonomi Publik, BPFE-Yogyakarta.

Musgrave, R.A. and P.B. Musgrave. 1989. Public Finance in Theory and Practive, McGraw-Hill, Inc.

Reksohadiprodjo, S. and A.B.P. Brodjonegoro. 1997. Ekonomi Lingkungan: Suatu Pengantar, BPFE-Yogyakarta.

Soekanto, Soerjono. 1999. Pengantar Penelitian Hukum. Universitas Indonesia Press. Jakarta. 
Syahza, Almasdi. 2011. Percepatan Ekonomi Pedesaan Melalui Pembangunan Perkebunan Kelapa Sawit. Jurnal Ekonomi Pembangunan. 12(2), 297-310.

Todaro, M. P., 2000. Ekonomi Pembangunan di Dunia Ketiga, Terjemahan oleh Haris Munandar, Edisi ke tujuh. Erlangga, Jakarta. Zen, Ratna Permatasari. 2008. Prospek Pengembangan Kelapa Sawit Perkebunan Rakyat (Studi Kasus : KUD-P3RSU, Desa Aek Nabara, Kecamatan Bilah Hulu, Kabupaten Labuhan Batu). Bachelor Thesis, Faculty of Agriculture, University of North Sumatra. Field. 